\title{
Neon isotopes indicate that Baffin Island and Iceland lavas share a common origin
}

FORREST HORTON $^{1}$, MARK D. KURZ ${ }^{1}$, JOSHUA CURTIS ${ }^{1}$, PAUL D. ASIMOW ${ }^{2}$ AND KENNETH A. FARLEY ${ }^{2}$

${ }^{1}$ Woods Hole Oceanographic Institution, Woods Hole, MA 02543; horton@whoi.edu

${ }^{2}$ Division of Geological and Planetary Sciences, California Institute of Technology, Pasadena CA 91125

Paleocene basaltic lavas exposed on Baffin Island have the highest ${ }^{3} \mathrm{He} /{ }^{4} \mathrm{He}$ found in any terrestrial igneous rocks and arguably contain the most pristine primordial mantle material exposed on Earth's surface. For decades, geochemists have speculated that Baffin Island lavas erupted above the protoIceland hotspot, despite (a) radiogenic isotope systematics that seem to preclude derivation of Iceland and Baffin lavas from common mantle components and (b) recent paleogeographic reconstructions that place the Iceland hotspot far from Baffin Island at the time of eruption. We analyzed noble gases ( $\mathrm{He}, \mathrm{Ne}$, and $\mathrm{Ar}$ ) from a new suite of Baffin Island lavas collected in 2018. Gases extracted by step crushing of olivine separates in vacuum had ${ }^{3} \mathrm{He} /{ }^{4} \mathrm{He}$ ratios (36-49 Ra) spanning the upper range of values observed previously in Baffin Island olivines and ${ }^{20} \mathrm{Ne} /{ }^{22} \mathrm{Ne}$ ratios ranging from 10.2 to 12.2 . The slope of the mixing line in ${ }^{20} \mathrm{Ne} /{ }^{22} \mathrm{Ne}^{-21} \mathrm{Ne} /{ }^{22} \mathrm{Ne}$ space is indistinguishable from subglacial Holocene glass from Iceland; data from both localities falls on the same isotope mixing line between atmosphere and a high ${ }^{20} \mathrm{Ne} /{ }^{22} \mathrm{Ne}$ mantle endmember. As in Iceland lavas, ${ }^{20} \mathrm{Ne} / 22 \mathrm{Ne}$ in our samples correlates positively with ${ }^{40} \mathrm{Ar} /{ }^{36} \mathrm{Ar}$. However, compared to Iceland, the ${ }^{3} \mathrm{He}$ concentrations are generally depleted relative to the high ${ }^{20} \mathrm{Ne} /{ }^{22} \mathrm{Ne}$ and ${ }^{40} \mathrm{Ar} /{ }^{36} \mathrm{Ar}$ mantle components in Baffin Island olivines, which we attribute to diffusive helium loss from olivines during subaerial eruption. Considering the diversity of $\mathrm{Ne}$ isotope mixing line slopes found in ocean island basalts worldwide, the excellent match between the new Paleocene Baffin data and Holocene Iceland data is strong evidence in support of previous speculation that Baffin Island and Iceland lavas share a common mantle origin. 